\title{
Reproductive ecology of coypu (Myocastor coypus Molina, 1782) in the Middle Delta of the Paraná River, Argentina
}

\author{
Courtalon, P. ${ }^{a *}, B o ́, R F^{a}$, Spina, $F^{a}{ }^{a}$, Jiménez, N. ${ }^{b}$, Cantil, L. ${ }^{b}$, Fernández, R. $^{c}$ and Porini, $G .^{d}$ \\ ${ }^{a}$ Grupo de Investigaciones en Ecología de Humedales, Departamento de Ecología Genética y Evolución, Facultad de \\ Ciencias Exactas y Naturales, Universidad de Buenos Aires, Intendente Güiraldes 2620, Ciudad Universitaria, \\ Pabellón II, 4to piso, Laboratorio 57, Ciudad Autónoma de Buenos Aires (C1428EHA), Argentina

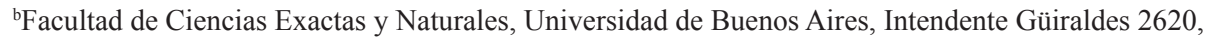 \\ Ciudad Universitaria, Pabellón II, Ciudad Autónoma de Buenos Aires (C1428EHA), Argentina \\ 'Dirección General de Recursos Naturales, Forestación y Economías Alternativas de Entre Ríos, \\ San Juan 430, Paraná, Entre Ríos (C3100), Argentina \\ dDirección de Fauna Silvestre, Secretaría de Ambiente y Desarrollo Sustentable de la Nación, \\ San Martín 451, 2do Piso, Ciudad Autónoma de Buenos Aires (C1004AAI), Argentina \\ *e-mail: pcourt@ege.fcen.uba.ar
}

Received: May 2, 2013 - Accepted: September 30, 2013 - Distributed: March 31, 2015

(With 2 figures)

\begin{abstract}
The objective of this study was to estimate and compare some important reproductive parameters of Myocastor coypus over time (June 2006-May 2008), in wetlands of the Middle Delta of the Paraná River (MD) Entre Ríos province, R. Argentina. Within the original coypu distribution range, the MD is among the areas of highest habitat suitability for the species. Coypus were captured and the following reproductive parameters were estimated on a monthly, seasonal and annual basis: pregnancy rate (PR), litter size (LS), gross productivity (GP) and annual production (AP). Statistical non-parametric tests were used for comparisons. Additionally, the expected birth date of each embryo and fetus was estimated by assigning it to a developmental stage category and considering the gestation period of the species. All the parameters showed high values and PR and LS differed significantly between the dry (2006) and humid years (2007). Two peaks of birth were detected, one in spring and another one in mid-autumn. The implications of these results for ensuring the sustainable management of this rodent are discussed.
\end{abstract}

Keywords: Myocastor coypus, Paraná River, peaks of birth, reproductive parameters, wetlands.

\section{Ecología reproductiva do coipo (Myocastor coypus) no Delta Meio do Río Paraná (Entre Ríos. Argentina)}

\section{Resumo}

O objetivo deste trabalho é a descripção e comparação ao longo do tempo (junho 2006 - maio 2008), de diversos parámetros da ecologia reprodutiva de Myocastor coypus nas terras úmidas do Delta Meio do Río Paraná (DM), una das zonas de maior aptidão de hábitat para a espécie dentro da sua área de distribuição original. Com base em capturas de exemplares estimaram-se en forma mensal, sazonal y anual, a taxa de prenhez (TP); o tamanho da camada (TC), a produtividade bruta (PB) e a produção anual (PA) e foram realizadas as comparações correspondentes mediante provas estatísticas não paramétricas. Alem disso, com base no estádio de desenvolvimento dos fetos y embriões observados, levando em consideração a duração do período de gestação, estimou-se quais teriam sido as datas de nascimento mais prováveis. Observaram-se valores relativamente altos para todos os parámetros e diferenças significativas entre as TP y os TC de anos secos (2006) e anos úmidos (2007). Também foram detectados dois picos de parição, um em plena primavera e o outro a meados do outono. Discutem-se as implicâncias destes resultados para assegurar o manejo sustentável do coipo, o principal recurso de fauna silvestre argentina.

Palavras-chave: Myocastor coypus, Río Paraná, picos de parição, parámetros reprodutivos, terras úmidas.

\section{Introduction}

The large alluvial wetlands systems of southern South America are characterised by a high wildlife diversity (Alho, 2008; Benzaquén et al., 2013), including large hystricomorphic rodents like the capybara (Hydrochoerus hydrochaeris, Linnaeus, 1776) (Verdade and Ferraz, 2006) and the coypu or false nutria (Myocastor coypus Molina, 
1782) (Parera, 2002; Bó et al., 2006). The coypu a large herbivore of semi-aquatic, nocturnal and gregarious habits (Kinler et al., 1987; Palomares et al., 1994; Guichón et al., 2003a; 2003b) usually found along the shore of freshwater marshes, ponds, and slow-flowing rivers and streams where it builds nests and burrows used as shelter for resting and reproduction (Courtalon et al., 1993; Merler et al., 1994; D'Adamo et al., 2000). Its distribution ranges from middle Bolivia and southern Brazil to southern Argentina (Woods et al., 1992; Bó et al., 2006; Colares et al., 2010).

The coypu has successfully invaded and is established in large areas of the US, Europe and Asia since 1930 (Carter and Leonard 2002; Bertolino et al., 2005). In these countries, it is considered as a pest causing economic loss to agriculture (Abbas, 1988) and damage to drainage systems (Verheyden and Abbas, 1996). In contrast, in Argentina the coypu is traditionally hunted for its fur and, to a lesser extent, for its meat (Porini et al., 2002). In this country, it is a major wildlife resource in terms of annual capture, people involved in the commercial chainand amount of capital mobilized (Porini et al., 2002; Bó et al., 2006). However, until recently, there have been only a few scattered studies on coypu in its natural and original environment. Therefore, the development and implementation of management measures such as hunting quota, animal size and openingend of the legal hunting season have littleornoscientific basis (Bó et al., 2006). In recent years, knowledge of the population ecology of the coypu in its original natural habitat has increased (Colantoni, 1993; Courtalon et al., 1993; Guichón et al., 2003a, b, c; Corriale, 2004; Nazar Anchorena, 2004; D'Adamo et al., 2000; Bó et al., 2008; Spina, 2008; Spina et al., 2009; Courtalon et al., 2011).

Myocastor coypus attains sexual maturity before complete development, at an age that varies with sex, weight (Crespo, 1974), season (Newson, 1966; Evans, 1970) and habitat quality (Atwood, 1950; Ehrlich, 1966; Peloquin, 1969). Crespo (1974) reported that, under normal conditions, first pregnancy occurs between 4 and 6 months of age, while males become sexually active at about 8 months of age. A mature male may mate repeatedly with many females in the water (Colantoni, 1993). Females are polyestrous with a continuous succession of cycles throughout the year (Kinler et al., 1987). Although these authors reported an estrous cycle of 17-19 days with a receptive period of 1-2 days, more recent studies conducted in captivity indicate that it is highly variable $(35.3 \pm 10.8$ days), with a slightly longer receptive period $(3.2 \pm 1.4$ days) (Felipe et al., 2001).

The gestation period lasts for 127-142 days (Gosling, 1974; Kinler et al., 1987) and usually two litters are produced per year with a mean litter size of 5.4 (range 2-7) (Crespo, 1974; Colantoni, 1993; Bó et al., 2006). Reproduction takes place throughout the year (Kinler et al., 1987; Felipe et al., 2006) and some authors propose that there are variable proportions of pregnant females and peaks of birth (Ehrlich, 1966, Bó et al., 2006). In Argentina, Crespo (1974) reported continuous reproductive activity during at least 9 months and attributed it to the lack of climaticconstraints. In contrast, low temperatures and/ or frosts are known to affect parturition and may cause decreased fertility rates or abortion (Gosling, 1981). In southern South America, coypu populations concentrate in ponds and freshwater marshes as they shrink during summer (Kinler et al., 1987). This is likely to favor malefemale encounter, which in turn may explain the increase in reproduction observed in summer. Accordingly, Bó et al. (2006) suggested the occurrence of birth peaks at certain months of the yearin most of the wetland systems of the Río de la Plata Basin, which may coincide with the initial phases of high- and low-water periods. Intermediate water levels would provide more suitable habitat conditions for breeding, thus increasing offspring survival (Bó et al., 2008). However, such periods would overlap with the start and end of the legal hunting season (Bó et al., 2006; Bó et al., 2008) implying a substantial loss in potential production, in both ecological and economic terms (Bó et al., 2006). This emphasizes the need to conduct a follow-up study of a wild coypu population for determining the actual occurrence of peaks of birth and estimating the reproductive parameters mentioned above, together with their possible seasonal variations.

Recently, the embryonic stages of coypu have been characterized in captive (Felipe et al., 2006; Felipe and Masson, 2008), and wild individuals (Spina et al., 2009). Information on the approximate age of embryos and fetuses from females captured during the study may allow to determine the expected birth date and to confirm or refute the occurrence of birth peaks, at least in the original distribution area of the species.

Information on the reproductive biology and ecology of $M$. coypus is scarce and was obtained mainly from captive individuals - breeding centers account for only $2 \%$ of total fur production- (Porini et al., 2002), and/or feral populations (Bó et al., 2006) in Argentina. Moreover, the studies conducted in the original distribution areas of the species are restricted to a limited period of the year. Based on the considerations mentioned above, the primary objective of this work was to estimate and compare some important reproductive parameters of Myocastor coypus from a follow-up study and to evaluate the actual occurrence of peaks of births. The study was conducted in the Middle Delta of the Paraná River, which is among the areas of highest habitat suitability for the species in the world (Kinler et al., 1987; Bó et al., 2006).

\section{Material and Methods}

The study was conducted in the area of the Delta islands at the Department of Victoria (DIV) in the Entre Ríos Province, Argentina, which is representative of the Middle Delta of the Paraná River (MD).

The study area was close to the Barrancoso stream, between $32^{\circ} 57^{\prime} 34.6 \mathrm{~S} / 60^{\circ} 05^{\prime} 39.1 \mathrm{~W}$ and $32^{\circ} 57^{\prime} 40.9$ $\mathrm{S} / 60^{\circ} 05^{\prime} 54.7 \mathrm{~W}$ and between $32^{\circ} 57^{\prime} 16.0 \mathrm{~S} / 60^{\circ} 05^{\prime}$ $46.4 \mathrm{~W}$ and $32^{\circ} 57^{\prime} 22.4 \mathrm{~S} / 60^{\circ} 06^{\prime} 02.0 \mathrm{~W}$ (Figure 1). 

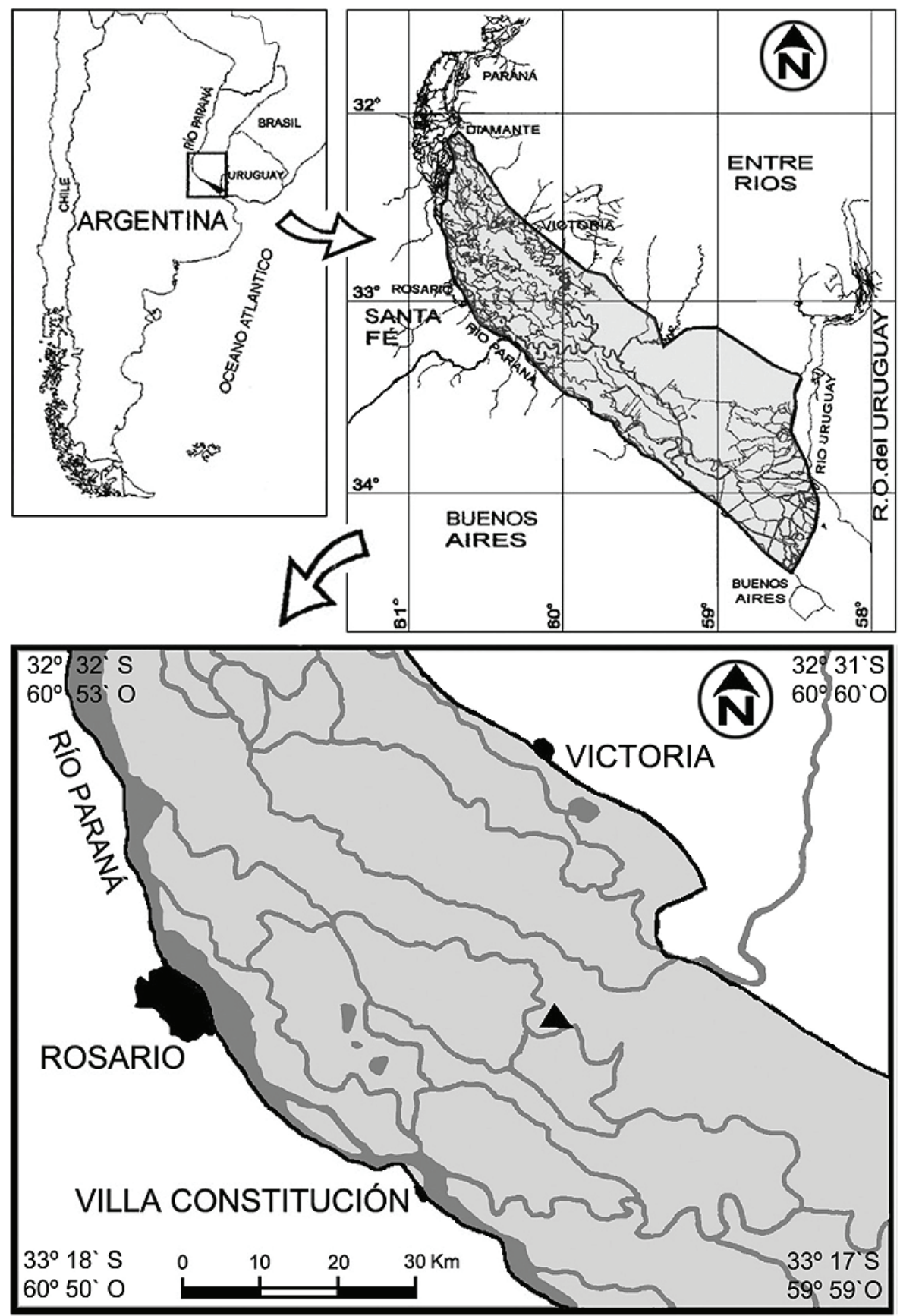

Figure 1. Location of the study area $(\boldsymbol{\Delta})$ in the Delta islands at the Department of Victoria (DIV), MiddleDelta of the Paraná River, Entre Ríos, Argentina.

The MD, which includes extensive fluvial wetlands with unique ecological and biogeographical features (Malvárez, 1999), is one of the most important coypu hunting areas in Argentina; here, M. coypus is a major wildlife resource for local people (Bó et al., 2010).

The climate is temperate and humid, with a mean annual temperature of $17.4{ }^{\circ} \mathrm{C}$ and an annual precipitation of $1016 \mathrm{~mm}$. The colder and warmer periods extend from May to September and from October to April, respectively
(Malvárez, 1999). The hydrological regime is influenced by the Paraná River, determining a period of "high waters" and a period of "low waters", which approximately coincide with the colder and warmer periods, respectively, the water level rising from early autumn (March-April) to mid-winter (July) and falling from early spring (September-October) to mid-summer (February) (Bó et al., 2008). Over the past decades, however, the region has been affected by increased hydrological and climate variability leading to 
more frequent and prolonged extreme events of droughts and floods (Camilioni, 2005; Bó et al., 2008).

The present study was conducted between June 2006 and May 2008. 2006was considered adry yearbut a severe flood (in terms of water column height) occurred from summer 2007 to next winter (humid year). Then, an extreme drought took place again from late 2007 and throughout 2008 (Bó et al., 2008).

Myocastor coypus specimens were caught monthly (between June 2006 and May 2008) in a hunting area of 105 ha, with the help of a local hunter using the captureremoval method (Krebs, 1999). The coypus were captured daily with 20 leg-hold traps according to the Agreement on International Humane Trapping System (AIHTS), approved by the Wildlife Department of Argentina. The traps were distributed in hunting subareas of 20 ha each, in the proximities of coypu tracks (nests, trails and feeding areas). On this basis, the capture method may not affect males and females differentially. In the hunting area, traps remained in the same subarea for 12 days, after which they were moved to other subarea for a further 12 days. The hunter was authorised by the Wildlife Department of Entre Ríos Province to capture coypu specimens during the authorised hunting season (AHS) and outside of it (OHS).

The following data were recordedover the study period: total number of examined females (TF), number of pregnant females (PF) and number of embryos or fetuses in their uterus. When possible, these data were used to estimate the following reproductive parameters on a monthly, seasonal and annual basis: pregnancy rate (PR), litter size (LS), gross productivity (GP) and annual production (AP). The PR was calculated as the proportion of PF divided by TF, LS as the number of embryos or fetuses per pregnant female, GP as the total number of embryos or fetuses divided by TF, and AP as the mean annual GP multiplied by annual female density (FD). The FD was estimated by a capture-removal method (Zippin, 1958) using the Removal Sampling Program (Pisces Conservation Ltd., 1992) taking into account that the sex proportion was estimated as 1:1 (Courtalon et al., 2011).

For 2006, data were obtained between June and $\operatorname{October}(\mathrm{N}=5)$-winter and spring- approximately during the legal hunting season. Duetofloodconditions,data for 2007 were obtained between May and September -autumn and winter- during the AHS and between November and December -spring- during the OHS $(\mathrm{N}=7)$. For 2008, data were only collected in March -summer- (OHS) and between April and May -autumn- because coypu habitat conditions and hunting were substantially affected by the severe drought and subsequent fires (natural and/or human-caused) that occurred in the study area (Taller Ecologista and LETyE-UNSAM, 2010).

Based on the facts mentioned above, the reproductive variables were compared among seasons within a same year and between years (PR, LS and GP) when the sample size was largeenough. Significant differences were tested by the Kolmogorov-Smirnov (K-S) or Kruskal-Wallis (K-W) non-parametric tests depending on the sample number (Siegel and Castellan, 1998) using the Program Statistica.

Each prenatal individual found in each pregnant female was assigned to one of the major four developmental stage categories proposed by Spina et al. (2009) as follows: $<60$-day gestation stage, 60 -day gestation stage, 90 -day gestation stage and 120-day gestation stage. This characterization was complemented by the following morphometric variables measured from each prenatal individual: umbilical cord diameter and length $(\mathrm{mm})$, body weight $(\mathrm{g})$, tail length $(\mathrm{mm})$, cephalic length $(\mathrm{mm})$, cephalo-caudal length $(\mathrm{mm})$ and length of fore and hind limbs $(\mathrm{mm})$. Then, a discriminant analysis (McLachlan, 2004) was used to assess if the latter three categories were properly discriminated by the morphological variables (either individually or combined).

The actual occurrence of one or more peaks of birth over the study period was evaluated by the expected birth date of each prenatal individual. This was estimated by relating the developmental stage category of the prenatal individual to the capture month of the pregnant female and considering a 132-day gestation period (Gosling, 1974).

\section{Results}

Table 1 shows the results obtained from the monthly samplings and the values of the reproductive parameters over the study period. Tables 2, 3 and 4 present a summary of the seasonal and annual mean (or median) values obtained for PR, LS and GP, respectively).

There were no significant differences in PR among seasons within the same year for any of the studied years (K-S test, $\mathrm{p}>0.05$ ). However, the annual mean values of PR increased significantly between 2006 (dry year) and 2007 (humid year) (K-S test, $\mathrm{p}<0.05$ ) (Table 2).

There were no significant differences in LS among seasons within the same year for any of the studied years (K-S test, $\left(\mathrm{p}>\right.$.05) ${ }_{2006} ; \mathrm{K}-\mathrm{W}\left[\mathrm{H}(3, \mathrm{~N}=64)_{2007}=\right.$ $4.2093 \mathrm{p}=0.2397]$ and $\mathrm{K}-\mathrm{W}\left[\mathrm{H}(1, \mathrm{~N}=48)_{2008}=0.851\right.$ $\mathrm{p}=0.356]$. However, the annual mean values of LS increased significantly between 2006 and 2007 (K-S test, $\mathrm{p}<0.001)$ (Table 3).

Differences in GP were not significantly different between seasons (K-S test, $\mathrm{p}>0.05$ for all cases) or between 2006 and 2007 (K-S test, $p>0.10$ ). However, GP varied considerably throughout 2007 (range: 0.13-6.38) (Table 4), when an extreme flood and a severe drought occurred at the beginning and end of this year, respectively.

Based on the annual female density values of 1.96 individuals/ha for 2006 and 0.77 individuals/ha for 2007 given by Courtalon et al. (2011), the estimated values of AP were 4.47 embryos or fetuses/ha for 2006 and 2.64 embryos or fetuses/ha for 2007.

The discriminant analysis showed that only body weight significantly distinguished the three developmental stages under consideration ( $\mathrm{N}=81$, Wilks Lambda: $0.455, \mathrm{~F}$ $(2.78)=46.599 \mathrm{p}<0.0001)$. Body weights of $4.26-23.76 \mathrm{~g}$, 
Table 1. Reproductive parameters of Myocastor coypus from an area of the Delta islands at the Department of Victoria (DIV). Data obtained between June 2006 and May 2008. TF: total number of examined females; PF: number of pregnant females; PR: pregnancy rate; LS: litter size; PI (prenatal individuals): total number of embryos or fetuses observed. GP: gross productivity.

\begin{tabular}{llcccccc}
\hline \multirow{2}{*}{2006} & TF & PF & PR & LS & PI & GP \\
& June & 15 & 5 & 0.33 & 3.80 & 19 & 1.27 \\
& July & 19 & 15 & 0.79 & 4.80 & 66 & 3.47 \\
& August & 7 & 4 & 0.57 & 5.25 & 21 & 3.00 \\
& September & 20 & 9 & 0.45 & 4.56 & 41 & 2.05 \\
& October & 9 & 3 & 0.33 & 5.00 & 15 & 1.67 \\
& May & 18 & 18 & 1.00 & 6.33 & 114 & 6.33 \\
& June & 17 & 14 & 0.82 & 6.50 & 91 & 5.35 \\
& July & 17 & 15 & 0.88 & 7.00 & 97 & 5.71 \\
& August & 13 & 11 & 0.84 & 7.91 & 83 & 6.38 \\
& September & 4 & 3 & 0.75 & 6.67 & 30 & 0.13 \\
& November & 2 & 2 & 1.00 & 7.50 & 15 & 0.13 \\
& December & 2 & 2 & 1.00 & 9.50 & 19 & 0.10 \\
& March & 20 & 14 & 0.70 & 6.57 & 92 & 4.60 \\
& April & 21 & 15 & 0.71 & 6.27 & 94 & 4.47 \\
\hline
\end{tabular}

Table 2. Pregnancy rate (PR) of Myocastor coypus from an area of the Delta islands at the Department of Victoria (DIV). Values obtained between June 2006 and May 2008, expressed as median followed byupper-lower quartiles in parenthesis. ND: no data. Summer and Fall 2007 and Summer 2008: a single value per season.

\begin{tabular}{cccc}
\hline & $\mathbf{2 0 0 6}$ & $\mathbf{2 0 0 7}$ & $\mathbf{2 0 0 8}$ \\
\hline Winter & 0.57 & 0.84 & ND \\
Spring & $(0.33-0.79)$ & $(0.82-0.88)$ & ND \\
& 0.39 & 0.88 & 0.7 \\
Summer & $(0.33-0.45)$ & $(0.75-1)$ & 0.83 \\
Fall & ND & 1 & $(0.71-0.95)$ \\
Median annual & ND & 1 & ND \\
PR & 0.45 & 0.88 & $(0.82-1)$
\end{tabular}

Table 3. Litter size (LS) of Myocastor coypus from an area of the Delta islands at the Department of Victoria (DIV). Values obtained between June 2006 and May 2008, expressed as median followed byupper-lower quartiles in parenthesis. ND: no data.

\begin{tabular}{cccc}
\hline & $\mathbf{2 0 0 6}$ & $\mathbf{2 0 0 7}$ & $\mathbf{2 0 0 8}$ \\
\hline Winter & 5 & 7 & ND \\
Spring & $(4-5)$ & $(6-8,5)$ & ND \\
Summer & 5 & 8 & $(7-10)$ \\
Fall & $(4-5)$ & 9.5 & 6.5 \\
Median annual & ND & $(5-14)$ & $(5-8)$ \\
LS & ND & 6 & $(5-7)$ \\
\end{tabular}

16.33-51.53 $\mathrm{g}$ and $76.25-158.35 \mathrm{~g}$ corresponded to the gestation stage categories of 60,90 and 120 days, respectively.

Figure 2 shows the expected proportion of births for each monthstudied, resulting from the developmental stage of embryos and fetuses at the time of female capture and from the gestation period of the species. Two parturition peaks were observed, one in mid- spring (October 2006) and the other in mid-autumn (May 2008). 
Table 4. Gross productivity (GP) of Myocastor coypus from an area of the delta islands at the Department of Victoria (DIV). Values obtained between June 2006 and May 2008, expressed as median followed byupper-lower quartiles in parenthesis. ND: no data. Summer and Fall 2007 and Summer 2008: a single value per season.

\begin{tabular}{cccc}
\hline & $\mathbf{2 0 0 6}$ & $\mathbf{2 0 0 7}$ & $\mathbf{2 0 0 8}$ \\
\hline Winter & 3 & 5.71 & ND \\
& $(1.27-3.47)$ & $(5.35-6.38)$ & ND \\
Spring & 1.84 & 0.13 & 4.6 \\
Summer & $(1.67-2)$ & $(0.13-0.13)$ & 5.01 \\
Fall & ND & 0.1 & $(4.4-5.5)$ \\
Median annual & ND & 6.33 & ND \\
GP & 2 & 5.35 & $(0.13-6.33)$ \\
\hline
\end{tabular}

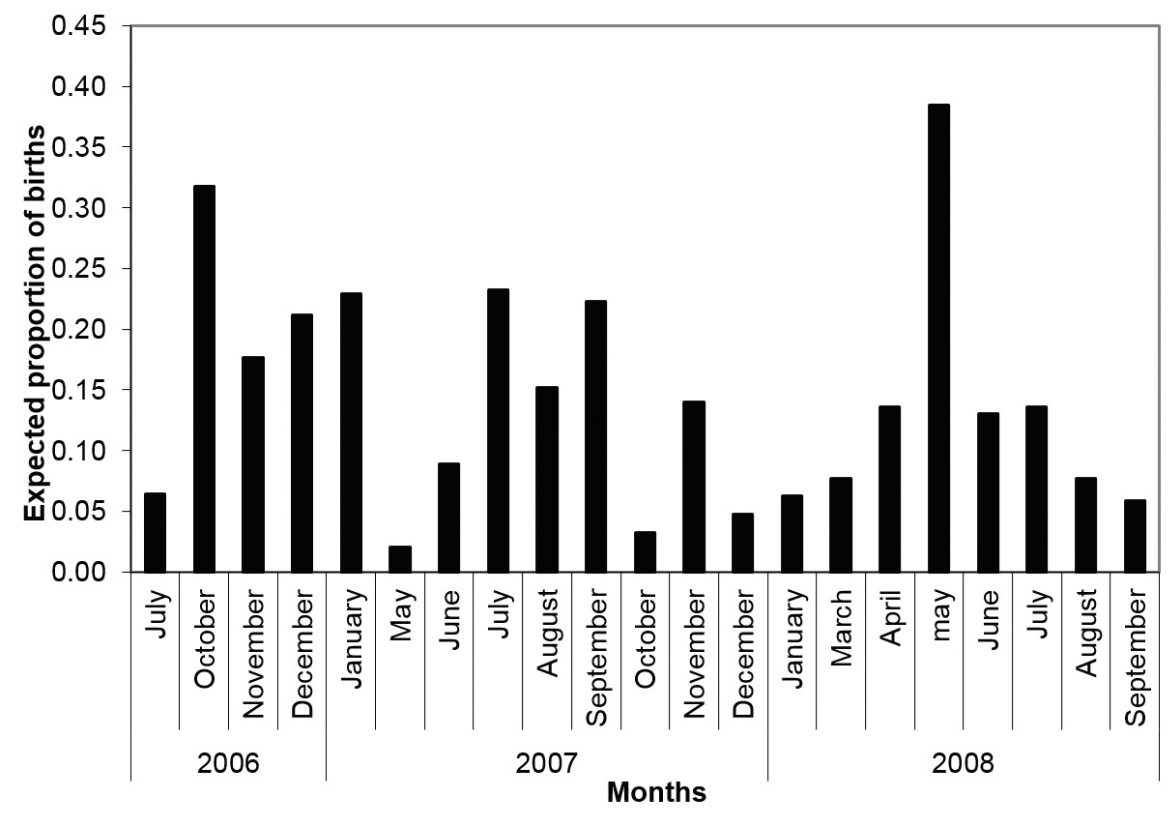

Figure 2. Expected proportion of births of Myocastor coypus(fetuses $\geq 120$ days /total number of embryos or fetuses present) for each month studied between 2006-2008 from an area of the Delta islands at the Department of Victoria (DIV), MiddleDelta of the Paraná River, Entre Ríos, Argentina.

\section{Discussion}

This work deals with the description of relevant parameters of the reproductive ecology of $M$. coypus. This type of research provides key information for improving and controlling coypu exploitation, in order toaccomplish effective and sustainable resourcemanagement.

In this study, the values of PR, LS, GP and AP for coypus from the study area coincide with those reported for other areas in Argentina (Crespo, 1974; Colantoni, 1993; Bó et al., 2006; Bó et al., 2008), and for other countries where the species was introduced (Ehrlich, 1966; Newson, 1966; Gosling, 1974; Willner et al., 1979; Kinler et al., 1987). The values of PR obtained in spring (0.39-0.88) are slightly higher than those reported by Crespo (1974) for wild areas in the north of Santa Fe province, Argentina during spring (0.25-0.67). Moreover, the range of annual PR values (0.49-0.90) includes the mean PR value of 0.68 estimated for a large number of hunting areas in different Argentine provinces, in the frame of the "Nutria Project" (Bó et al., 2006).

Similarly, the values of LS obtained in this study (5-7 embryos/female) are higher than those estimated by Crespo (1974) (4.5 embryos/female) and Colantoni (1993) (3.82 embryos/female) for central-east Buenos Aires province, and coincide with the value of 5.4 embryos/ female reported in the "Nutria Project" (Bó et al., 2006).

It is interesting to note that the values of GP and AP were high (2.28-3.44 embryos or fetuses/female for GP and 2.64-4.47 coypus/ha for AP) even in years of adverse climate-hydrological conditions, indicating that coypu has 
a high natural productivity. This also suggests that coypu populations would show a remarkable ability to recover from the heavy hunting pressure in the study area and other wetlands of Argentina.

Drought perturbation is likely to have a more pronounced effect on the reproductive ecology of $M$. coypus than flood perturbation, based on the lower values observed for almost all the studied parameters (many of which were significantly lower) in a dry year (2006 and 2008) as compared to a humid year (2007). This would be related to a decrease in the availability of water levels suitable for different activities such as courtship, mating and parental care (Kinler et al., 1987; Guichón et al., 2003b). The high AP values observed in 2006 would be due to the negative effect that an extreme flood has on the density of coypus, and not necessarily on their reproductive capacity. This variability in the density would be related to dispersion or migration in search of more favorable habitats (Bó and Malvárez, 1999; Bó et al. 2008).

On the other hand, this study provided evidence that the different developmental stages (especially the older categories) can be easily distinguished by body weight. The present study is in agreement with previous work reporting that wild coypus undergo reproduction all year round and emphasizes the occurrence of two birth peaks: one in mid- autumn (at the beginning of the "high water" period) and the other in mid-spring (at the beginning of the "low water" period) supporting the suggestion made by Bó et al. (2006). However, it should be kept in mind that the number of births may be slightly overestimated because the death of some embryos or fetuses is not considered.

In many coypu hunting areas of Argentina such as the Middle Delta of the Paraná River, the opening and closure of the legal hunting season coincide with peaks of birth. For this reason it is recommended that hunting should be restricted to winter, and banned during extremely dry years or a few months before a severe flood event. These measures may contribute effectively to the sustainable management of $M$. coypus in the vast wetland areas of Argentina and in a large part of its original natural distribution.

\section{Acknowledgements}

We are grateful to Carlos Hevia and his family for their hospitality and help in the field. This work was carried out in the frame of the "Nutria Project, basic ecological studies for the sustainable management of Myocastor coypus in Argentina". It is part of a cooperation agreement between the Dirección de Fauna Silvestreof the Secretaría de Ambiente y Desarrollo Sustentable of Argentina, which provided financial support, and the Grupo de Investigaciones en Ecología de Humedales, Facultad de Ciencias Exactas y Naturales, Universidad de Buenos Aires (Argentina).

\section{References}

ABBAS, A., 1988. Impact du ragondin (Myocastor coypus Molina) sur une culture du mais (Zea mays L.) dans le Marais Poitevin. Acta Oecologica, vol. 9, p. 173-189.
ALHO, CJR., 2008. Biodiversity of the Pantanal: response to seasonal flooding regime and to environmental degradation. Brazilian Journal of Biology $=$ Revista Brasileira de Biologia, vol. 68, no. 4, supplement, p. 957-966. http://dx.doi.org/10.1590/ S1519-69842008000500005. PMid:19197468

ATWOOD, EL., 1950. Life history studies of nutria, or coypu, in coastal Louisiana. The Journal of Wildlife Management, vol. 14, no. 3, p. 249-265. http://dx.doi.org/10.2307/3796144.

BENZAQUÉN, L., BLANCO, DE., BÓ, RF., KANDUS, P., LINGUA, GF., MINOTTI, P., QUINTANA, RD., SVERLIJ, S. and VIDAL, L., 2013. Inventario de los humedales de Argentina: sistemas de paisajes de humedales del corredor fluvial Paraná Paraguay. Argentina: Secretaría de Ambiente y Desarrollo Sustentable de la Nación. Proyecto GEF 4206 PNUD ARG 10/003.

BERTOLINO, S., PERRONE, A. and GOLA, L., 2005. Effectiveness of coypu control in small Italian wetland areas. Wildlife Society Bulletin, vol. 33, no. 2, p. 714-720. http://dx.doi.org/10.2193/00917648(2005)33[714:EOCCIS]2.0.CO;2

BÓ, RF. and MALVÁREZ, AI., 1999. Las inundaciones y la biodiversidad en humedales: un análisis del efecto de eventos extremos sobre la fauna silvestre. In MALVÁREZ, AI. (Ed.). Tópicos sobre humedales subtropicales y templados de Sudamérica. Montevideo: Oficina Regional de Ciencia y Tecnología de la UNESCO para América Latina y el Caribe. p. 147-168.

BÓ, RF., PORINI, GM., CORRIALE, MJ. and ARIAS, SM., 2006. Proyecto Nutria: estudios ecológicos básicos para el manejo sustentable de Myocastor coypus en Argentina. In BOLKOVIC, ML. and RAMADORI, D. (Eds.). Manejo de Fauna Silvestre en Argentina: programas de uso sustentable. Buenos Aires: Dirección de Fauna Silvestre, Secretaría de Ambiente y Desarrollo Sustentable de la Nación. p. 93-104.

BÓ, RF., COURTALON, P., SPINA, F., FERNÁNDEZ, R. and PORINI, G., 2008. Los eventos extremos de sequía e inundación y sus consecuencias sobre el coipo o nutria (Myocastor coypus Molina, 1782) y la actividad de caza en el Delta Medio del Río Paraná. In VOLPEDO, AV. and REYES, LF. (Eds.). Efecto de cambios globales sobre la biodiversidad: efecto de cambios globales sobre los humedales de Iberoamérica. La Habana: Programa Iberoamericano de Ciencia y Tecnología para el Desarrollo. p. 167-192.

BÓ, RF., FERNÁNDEZ, R., COURTALON, P., PORINI, G. and QUINTANA, RD., 2010. Caza de Fauna Silvestre. In Taller Ecologista-Rosario and LETyE-UNSAM (Eds.). Humedales del Paraná: biodiversidad, usos y amenazas en el Delta Medio. Programa de Subvenciones para Ecosistemas (EGP)UICN- The Netherlands. Rosario. p. 41-44.

CAMILIONI, I., 2005. Variabilidad y tendencias hidrológicas en la Cuenca del Plata. In BARROS, V., MENÉNDEZ, A. and NAGY, C. (Eds.). El Cambio Climático en el Río de la Plata. Buenos Aires: Consejo Nacional de Investigaciones Científicas y Técnicas (CONICET). p. 21-32.

CARTER, J. and LEONARD, BP., 2002. A review of the literature on the worldwide distribution, spread of, and efforts to eradicate the coypu (Myocastor coypus). Wildlife Society Bulletin, vol. 30, p. 162-175.

COURTALON, P., BENTHAM, C., CROJETHOVICH, A. and RAFFO, L., 1993. Estudio de selección de hábitat y estimación de la densidad del coipo Myocastor coypus en el Parque Natural Costanera Sur, Capital Federal. In Actas de las Primeras Jornadas 
Nacionales y Sextas Regionales de Medio Ambiente. Argentina: Universidad Nacional de La Plata. p. 1-42. vol. 1.

COURTALON, P., SPINA, F., PORINI, G. and BÓ, RF., 2011. Population dynamics of coypus (Myocastor coypus) during and outside of the authorized hunting season in the floodplain of the Paraná River, Argentina. Mastozoología Neotropical, vol. 18, no. 2 , p. 217-225.

COLANTONI, LO., 1993. Ecología poblacional de la nutria (Myocastor coypus) en la provincia de Buenos Aires. Fauna y Flora Silvestres, vol. 1, p. 1-25.

CORRIALE, MJ., 2004. Evaluación del estado poblacional y patrón de uso de hábitat del coipo (Myocastor coypus) en humedales urbanos. Buenos Aires: Departamento de Ecología Genética y Evolución, Facultad de Ciencias Exactas y Naturales, Universidad de Buenos Aires. 98 p. Tesis de Licenciatura en Ciencias Biológicas.

CRESPO, JA., 1974. Observaciones sobre la reproducción de la nutria en estado silvestre. In 1 Congreso Argentino de Producción Nutriera, 1974, Provincia de Santa Fe, Argentina. p. 60-73.

COLARES, IG., OLIVEIRA, RNV., LIVEIRA, RM. and COLARES, EP., 2010. Feeding habits of coypu (Myocastor coypus Molina 1782) in the wetlands of the Southern region of Brazil. Anais da Academia Brasileira de Ciencias, vol. 82, no. 3, p. 671-678. http:// dx.doi.org/10.1590/S0001-37652010000300015. PMid:21562696

D’ADAMO, P., GUICHÓN, M., BÓ, RF. and CASSINI, M., 2000. Habitat use of the coypu Myocastor coypus in agro-systems of the Argentinean Pampas. Acta Theriologica, vol. 45, p. 25-33. http://dx.doi.org/10.4098/AT.arch.00-3.

EHRLICH, S., 1966. Ecological aspects of reproduction in nutria, Myocastor coypus (Mol.). Mammalia, vol. 30, no. 1, p. 142-152. http://dx.doi.org/10.1515/mamm.1966.30.1.142.

EVANS, J., 1970. About nutria and their control. Denver: Bureau of Sport Fisheries and Wildlife Research Center. Resource Publication, no. 86.

FELIPE, AE., CABODEVILA, J. and CALLEJAS, S., 2001. Caracterización del ciclo estral de Myocastor coypus (coipo) a través de colpocitología. Mastozoología Neotropical, vol. 8, p. 129-137.

FELIPE, AE., MASSON, PG., RODRÍGUEZ, JA. and ALZOLA, RH., 2006. External morphological characterization of 60-days gestation Myocastor coypus (coypu) fetuses. International Journal of Morphology, vol. 24, p. 71-76.

FELIPE, AE. and MASSON, PG., 2008. Observations on the fetal morphology in Myocastor coypus bonariensis (coypu) (Rodentia, Myocastoridae). Anatomia, Histologia, Embryologia, vol. 37, no. 6, p. 469-474. http://dx.doi.org/10.1111/j.1439-0264.2008.00884.x. PMid:19032632

GOSLING, LM., 1974. The coypu in the East Anglia. Transactions Norfolk Norwich National Society, vol. 23, p. 49-59.

GOSLING, LM., 1981. The Coypu. In BOYLE, CL. (Ed.). The RSPCA book of British wild mammals Collins. London. p. 129-135.

GUICHÓN, ML., BENÍTEZ, PG., ABBA, A., BORGNIA, M. and CASSINI, MH., 2003a. Foraging behaviour of coypu Myocastor coypus: why do coypus consume aquatic plants? Acta Oecologica, vol. 24, no. 5-6, p. 241-246. http://dx.doi. org/10.1016/j.actao.2003.08.001.

GUICHÓN, ML., BORGNIA, M., RIGHI, CF., CASSINI, GH. and CASSINI, MH., 2003b. Social behaviour and group formation in the coypus (Myocastor coypus) in the Argentinean pampas. Journal of Mammalogy, vol. 84, no. 1, p. 254-262. http://dx.doi. org/10.1644/1545-1542(2003)084<0254:SBAGFI>2.0.CO;2.

GUICHÓN, ML., DONCASTER, CP. and CASSINI, MH., 2003c. Population structure of coypus (Myocastor coypus) in their region of origin and comparison with introduced populations. Journal of Zoology (London, England), vol. 261, no. 3, p. 265-272. http:// dx.doi.org/10.1017/S0952836903004187.

KINLER, NW., LINSCOMBE, G. and RAMSEY, PR., 1987. Nutria. In NOWAK, M., BAKER, JA., OBBARD, ME. and MALLOCH, B. (Eds.). Ontario: Wild Furbearer Management in North America/Ontario Trappers Asociation. p. 327- 343.

KREBS, CJ., 1999. Ecological methodology. 2nd ed. Menlo Park: Addison-Welsey Educational. 620 p.

MALVÁREZ, AI., 1999. El Delta del Río Paraná como mosaico de humedales. In MALVÁREZ, AI. (Ed.). Tópicos sobre humedales subtropicales y templados de Sudamérica. Montevideo: Oficina Regional de Ciencia y Tecnología de la UNESCO para América Latina y el Caribe. p. 35-54.

MCLACHLAN, GJ., 2004. Discriminant analysis and statistical pattern recognition. New York: John Wiley \& Sons.

MERLER, J., BÓ, R., QUINTANA, R. and MALVÁREZ, A., 1994. Habitat studies at different spatial scales for multiple conservation goals in the Paraná River Delta (Argentina). International Journal of Ecology and Environmental Sciences, vol. 20, p. 149-162.

NAZAR ANCHORENA, S., 2004. Estimación de la edad en Myocastor coypus (Molina, 1782) y sus implicancias en la ecología y el manejo sustentable de la especie. Buenos Aires: Departamento de Ecología, Genética y Evolución, Facultad de Ciencias Exactas y Naturales, Universidad de Buenos Aires. 84 p. Tesis de Licenciatura en Ciencias Biológicas.

NEWSON, RM., 1966. Reproduction in the feral coypu (Myocastor coypus). Symposia of the Zoological Society of London, vol. 15, p. 323-334

PARERA, A., 2002. Los mamíferos de la Argentina y la región austral de Sudamérica. Buenos Aires: El Ateneo.

PALOMARES, F., BÓ, RF., BELTRÁN, J., VILLAFAÑE, G. and MORENO, S., 1994. Winter circadian activity pattern of free-ranging coypus in the Paraná River Delta, eastern Argentina. Acta Theriologica, vol. 39, p. 83-88. http://dx.doi.org/10.4098/ AT.arch.94-10.

PELOQUIN, EP., 1969. Growth and reproduction of the feral nutria Myocastor coypus (Molina) near Corvallis. Oregon: Oregon State University. Master's Thesis.

PORINI, G., ELISETCH, M. and SEEFELD, C., 2002. Manual de identificación de especies de interés peletero. Buenos Aires: International Fur Trade Federation and Federación Argentina de Comercio e Industria de la Fauna. p. 208.

SPINA, F., 2008. Ecología reproductiva y parámetros poblacionales del coipo (Myocastor coypus) en el valle de inundación del río Paraná (Departamento Victoria, Provincia de Entre Ríos, Argentina). Argentina: Facultad de Ciencias Exactas y Naturales. Universidad de Buenos Aires. 62 p. Tesis de Licenciatura en Ciencias Biológicas.

SPINA, F., COURTALON, P., PORINI, G. and BÓ, RF., 2009. Estimation of the birth season of Myocastor coypus (Molina, 1782) by characterisation of prenatal developmental stages. Mammalia, vol. 73, no. 3, p. 1-3. http://dx.doi.org/10.1515/MAMM.2009.040. 
SIEGEL, S. and CASTELLAN, NJ., 1998. Estadistica no paramétrica. Buenos Aires: Trillos.

Taller Ecologista, LETyE-UNSAM, 2010. Humedales del Paraná: biodiversidad, usos y amenazas en el Delta Medio. Programa de Subvenciones para Ecosistemas (EGP)- UICN-The Netherlands. Rosario. p. 66.

VERDADE, LM. and FERRAZ, KM., 2006. Capybaras in an anthropogenic habitat in Southeastern Brazil. Brazilian Journal of Biology $=$ Revista Brasileira de Biologia, vol. 66, no. 1B, p. 371-378. http://dx.doi.org/10.1590/S1519-69842006000200019. PMid:16710529

VERHEYDEN, C. and ABBAS, A., 1996. Impact du ragodin sur le milieu. In JOUVENTIN, P., MICOL, T., VERHEYDEN, C. and GUÉDON, G. (Eds.). Le ragodin: biologie et méthodes de limitation des populations. Paris: Association de Coordination Technique Agricole. p. 44-54.

WILLNER, GR. and CHAPMAN, JA. and PURSLEY, D., 1979. Reproduction, physiological responses, food habits, and abundance of nutria on Maryland marshes. Wildlife Society. Wildlife Monographs, no. 65.

WOODS, CA., CONTRERAS, L., WILLER-CHAPMAN, G. and WHIDDEN, HP., 1992. Myocastor coypus. In VERTS, BJ., BEST, TL., CAMERON, GN. and ANDERSON, YS. (Eds.). The American Society of Mammalogists. p. 1-8. Mammalian Species, no. 398.

ZIPPIN, C., 1958. The removal method of population estimation. The Journal of Wildlife Management, vol. 22, no. 1, p. 82-90. http://dx.doi.org/10.2307/3797301. 